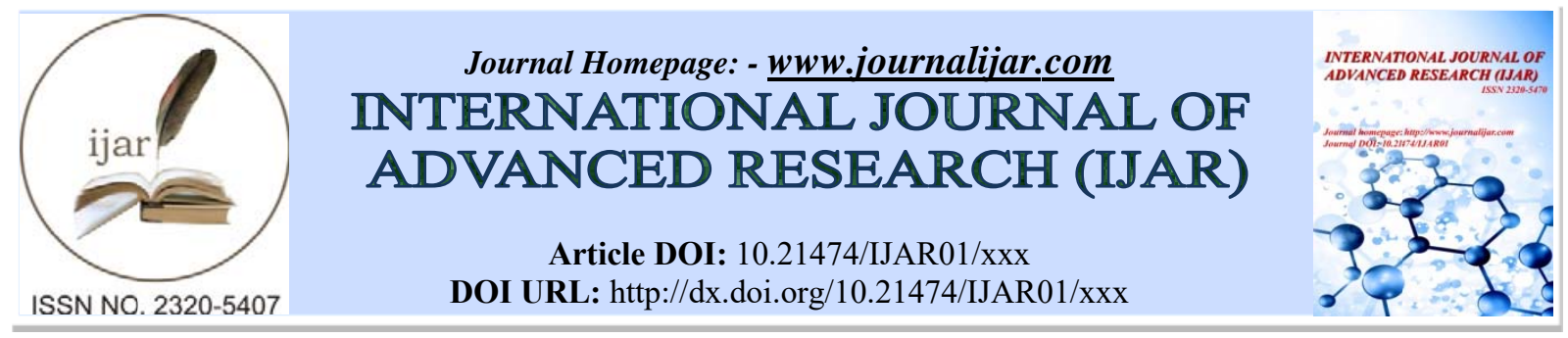

RESEARCH ARTICLE

\title{
GROWTH AND CONTRIBUTION OF HORTICULTURE OF HIMACHAL PRADESH: A CASE STUDY OF KOTGARH VALLEY OF SHIMLA DISTRICT, HIMACHAL PRADESH.
}

Richa Kaushal ${ }^{1}$, D. S. Thakur ${ }^{1}$ and Arjun Kumar ${ }^{2}$.

1. Department of Economics, Himachal Pradesh University, Shimla (H.P.) India.

2. Department of Civil Engineering, Arni University, Kathgarh, Kangra (H.P.) India.

\section{Manuscript Info}

\section{Manuscript History}

Received: 4 May 2017

Final Accepted: 6 June 2017

Published: July 2017

\section{Key words:-}

Resource use efficiency, Cobb-Douglas, Kotgarh, Shimla, Himachal Pradesh

\section{Abstract}

The Kotgarh valley is the apple heartland of Himachal; also known as the apple bowl of India. It is located at about 6,500 feet above sea level. The study is aimed to analyze the growth and contribution of horticulture crops (Apple, Pear, Plum and Almond) in this region of Himachal Pradesh. A data set of 140 samples of horticulture farmers (marginal, small, semi-medium and medium farmers) in year 20162017 has been used in this study. The results showed the total cost of horticulture cultivation is ₹ $2,45,124.79$ per hectare for all marginal, small, semi-medium and medium farmers; which is highest (₹ $3,45,110.55)$ for marginal farmers and minimum (₹ 1,80,924.52) for medium farmers. The different costs have been studied. The overall C3 cost is ₹ 4,30,863.77. The average yield is ₹ 8,86,258.29 per hectare. It ranged from ₹ 9,86,313.35 on medium farms to ₹ $7,70,226.50$ on small farms. Net gain over different costs per hectare is also studied. The farm business income (FBI), family labour income (FLI), farm investment income (FII) and net income over cost C3 are ₹ $3,96,008.71$, ₹ $3,96,008.71$, ₹ $3,66,593.74$ and ₹ $2,10,269.70$ respectively. To study the elasticity of different input variables, the log linear type Cobb-Douglas production function has been applied. Functional analysis of horticulture crops revealed that, cultivated human labour, plucking \& carriage charge/harvesting Charging, value of packing material, freight charges, transportation charges and marketing charges i.e. $-3.0166,3.0071,0.1717,0.2595,0.1882$ and 0.3256 respectively. These coefficients are significant with $>95 \%$ confidence, which indicated that if expenses made on these resources, then it will gives profitable returns.

Copy Right, IJAR, 2017,. All rights reserved.

\section{Introduction:-}

Himachal Pradesh has been endowed with a wide range of agro climatic conditions due to which a large number of horticulture commodities like fruit crops (from temperate to sub tropical), flowers, vegetables, mushrooms, hops, tea, medicinal \& aromatic plants etc. are successfully grown here. Depending upon the agroclimatic conditions and the suitability of a particular area for the growing of specific fruit crops in that area, the State is broadly divided into four agroclimatic zones (Figure 1) as described in the table 1.

Corresponding Author:- Richa Kaushal.

Address:- Department of Economics, Himachal Pradesh University, Shimla (H.P.) India. 
Table 1:- The agroclimatic zones of Himachal Pradesh.

\begin{tabular}{|c|l|l|l|l|}
\hline S.No & $\begin{array}{l}\text { ZONE } \\
\text { DESCRIPTION }\end{array}$ & $\begin{array}{l}\text { ELEVATION } \\
\text { RANGE (meters } \\
\text { amsl) }\end{array}$ & $\begin{array}{l}\text { RAINFALL } \\
\text { (cms) }\end{array}$ & SUITABLE FRUIT CROPS \\
\hline 1 & $\begin{array}{l}\text { Low Hill and } \\
\text { Valley areas near } \\
\text { the plains }\end{array}$ & $365-914$ & $60-100$ & $\begin{array}{l}\text { Mango, Litchi, Guava, Loquat, Citrus Fig, } \\
\text { Ber, Papaya, Early varieties of Grapes, Jack } \\
\text { Fruit, Banana, Low chilling varieties of } \\
\text { Peach, Plum and Pear, Strawberry. }\end{array}$ \\
\hline 2 & $\begin{array}{l}\text { Mid Hills (Sub } \\
\text { Temperate) }\end{array}$ & $915-1523$ & $90-100$ & $\begin{array}{l}\text { Stone Fruits (Peach, Plum, Apricot, } \\
\text { Almond), Persimmon, Pear, Pomegranate, } \\
\text { Pecan nut, Walnut, Kiwi Fruit, Strawberry. }\end{array}$ \\
\hline 3 & $\begin{array}{l}\text { High Hills and } \\
\text { Valleys in the } \\
\text { interiors } \\
\text { (Temperate) }\end{array}$ & $1524-2742$ & $90-100$ & $\begin{array}{l}\text { Apple, Pear (Soft), Cherry, Almond, } \\
\text { Walnut, Chestnut, Hazel- nut, Strawberry. }\end{array}$ \\
\hline 4 & $\begin{array}{l}\text { Cold and Dry Zone } \\
\text { (Dry Temperate) }\end{array}$ & $1524-3656$ & $24-40$ & $\begin{array}{l}\text { Apples, Prunes, Drying type of Apricot, } \\
\text { Almond, Chilgoza, Pistachionut, Walnut, } \\
\text { Hazel-nut, Grapes and Hops. }\end{array}$ \\
\hline
\end{tabular}

Source: State Department of Horticulture (Government of Himachal Pradesh).

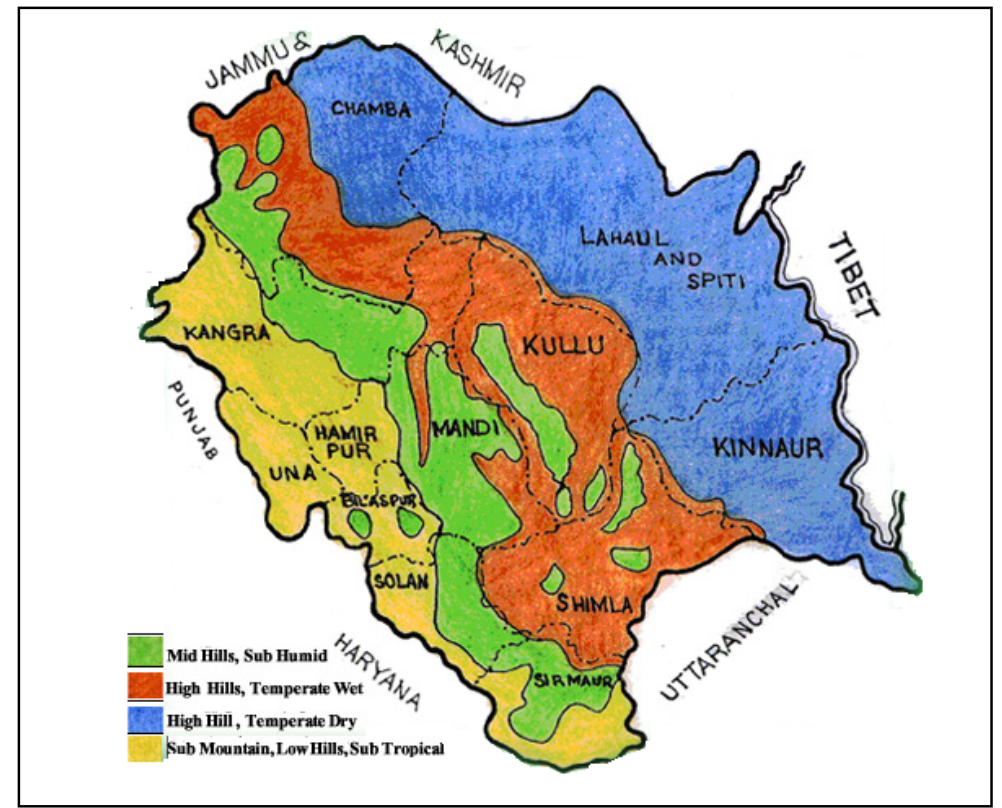

Figure 1:- Agroclimatic zones of Himachal Pradesh. (Source: http://www.hpagriculture.com)

Total area under Horticulture in Himachal Pradesh (2015-16) is about 226799 Hectare. Among which apple covers an area of about 110679 hectare, other temperate fruits 27908, nuts \& dry fruits 10491, citrus fruits 24063 and other sub-tropical fruits are grown in 53658 hectare. The total fruit production is 928829 M.T. Among which apple has production of 777126 M.T; other temperate fruits have 70259 M.T.; nuts \& dry fruits have 3373 M.T.; citrus have 26624 M.T.; mango 37628 M.T. and other sub-tropical fruits have 13900 M.T. productions [State Department of Horticulture (Government of Himachal Pradesh)].

The study region Kotgarh valley is situated $82 \mathrm{~km}$ from Shimla on the old Hindustan-Tibet road and located at about 6,500 feet above sea level. In the study the growth and contribution of horticulture crops (Apple, Pear, Plum and Almond) in this region of Shimla district of Himachal Pradesh studied. A data set of 140 samples of horticulture farmers in year 2016-2017 has been collected for this purpose. The study the elasticity of different input variables, the log linear type Cobb-Douglas production function has been applied. 
Data:-

Keeping in view the agro-climatic conditions of the state, mid hill zone is selected for the present investigation. From the this zone, the Kotgarh valley (Upper Shimla) Block Narkanda of Shimla district of Himachal Pradesh has been selected for the study. The farmers with different farm sizes have been categorized as shown in Table 2 .

Table 2:- The farmers with different farm sizes have been categorized as.

\begin{tabular}{|c|c|}
\hline Category & Farm Size (Hectares) \\
\hline Marginal farmer & $<1.0$ \\
\hline Small farmer & $1.0-2.0$ \\
\hline Semi-medium & $2.0-4.0$ \\
\hline Medium farmer & $4.0-10.0$ \\
\hline
\end{tabular}

After that, the process of multistage stratified random sampling has been adopted. Then, three villages from each panchayat have been selected randomly. A data set of 140 samples of horticulture farmers in year 2016-2017 has been collected for this study.

\section{Methodology and Analysis:-}

\section{Cost of Cultivation:-}

Cost of cultivation is the total expenses made in cultivating horticulture crops. This cost is worked out by input wise and operation wise together with their percentage to the total. A detailed cost of cultivation on ABC cost measures (Manual on Cost of Cultivation Survey, Ministry of Statistics and Programme Implimentation, Government of India) is also worked out. All types of appropriations and imputations of various costs are taken as per the guidelines given in the manual.

\section{Cost A1:-}

Cost A1 consists of all actual expenses in cash and kind, incurred in cultivation by the farmers. It includes the following costs:

1. Human Labour ( in mandays)

2. Land in Hectare

3. Value of manure \& fertilizer (₹)

4. Cost of Plants (₹)

5. Value of Insecticides \& pesticides (₹)

6. Plucking \& Carriage Charge/Harvesting Charging $(₹)$

7. Value of packing Matiral (₹)

8. Freight Charges (₹)

9. Transportation Charges (₹)

10. Marketing Charges (₹)

a. Cost $\mathbf{A 2}=$ Cost A1 + rent paid for leased in land.

b. Cost $\mathbf{B} 1=$ Cost $A 1+$ interest on fixed capital (excluding land). $12 \%$

c. Cost $\mathbf{B} 2=$ Cost $\mathrm{B} 1+$ rental value of owned land + rent for leased in land.

d. Cost $\mathbf{C 1}=$ Cost $\mathrm{B} 1+$ imputed value of family labour.

e. Cost $\mathbf{C 2}=\operatorname{Cost} \mathrm{B} 2+$ imputed value of family labour.

f. Cost $\mathbf{C} 3=$ Cost $\mathrm{C} 2+10$ percent of cost $\mathrm{C} 2$ as management cost.

\section{Income Measures:-}

The profitability of horticulture cultivation can be ascertained by means of various income measures such as gross income, farm business income, own farm business income, family labour income and net income (Kahlon and Singh 1984, Raju and Rao 1990).

\section{Gross Income:-}

Gross income represents the total value of the produce which is valued at the prevailing market price.

\section{Farm Business Income:-}

The farm business income is computed by deducting cost A1 from gross income. This income provides profitability of the farm activity before considering the rent and other imputed values of expenses. 


\section{Own Farm Business Income:-}

Own farm business income is obtained by deducting cost A2 from gross income. This measure of income depicts the profitability of firm after considering the lease rent paid by the farmer if any, but before the imputation of rent in case of own farm.

\section{Family Labour Income:-}

It was arrived by deducting Cost B2 from gross income. This measure provides the profitability of the farm after the imputation of lease rent but before the imputation of family labour.

\section{Net Income:-}

Net income was computed by deducting cost C3 from gross income. This measure of income is obtained after the imputation of all expenses including the allowances for managerial expenses.

\section{Resource use efficiency:-}

The use of different inputs in production of horticulture crops on sample farm was studied, to analyze the resource use efficiency in horticulture crops. The different variables used in the production function are as under (Patil and Khobarkar, 2013, Sureshkumar et al., 2014).

The general form of function

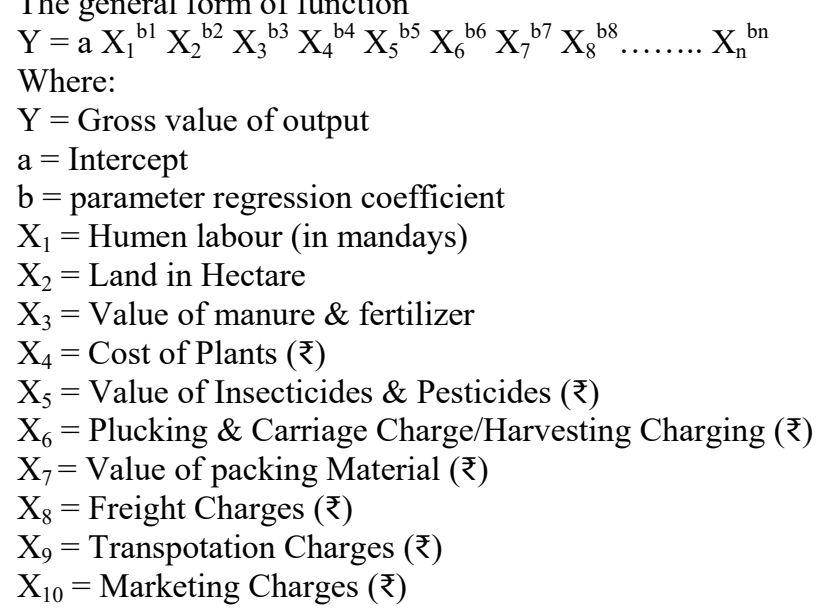

Where $X_{i}$ is the variable resources measure, $Y$ is the output, ' $a$ ' is constant and bi estimates give extent of relationship between $\mathrm{X}$ and $\mathrm{Y}$ and when $\mathrm{X}$ is at different magnitudes. The $\mathrm{b}$ coefficient also represents the elasticity of production. The log linear function of Cobb-Douglass used for present study, because it gives rationale value of $\mathrm{R}^{2}$ and adjusted $\mathrm{R}^{2}$ than other functions like Non-linear function and Quadratic function.

\section{Results and Discussions:-}

The choice of crops to be grown and the area to be allocated under a crop depends on the prices of output, productivity level, technology available and the level and prices of inputs used in their production. The knowledge of input use, cost structure and returns from the cultivation of crops helps in formulating the policies at macro and micro levels. This knowledge is very useful for crops taken mainly for the market purpose. This study has been carried to find out input use, cost structure and profitability of horticulture crops in Kotgarh valley of Shimla district in Himachal Pradesh.

\section{Input Pattern:-}

The study analyses the growth and contribution of horticulture crops (Apple, Pear, Plum and Almond) in Kotgarh valley of Shimla district in Himachal Pradesh. Therefore, cost of cultivation has paramount importance in determining the net income from it. The details of per hectare component wise costs for cultivation on different size of farms are studied and results are furnished in Table 3.

The results shows the total cost of horticulture cultivation is ₹ 2,45,124.79 per hectare for all marginal, small, semimedium and medium farmers; which is highest $(₹ 3,45,110.55)$ for marginal farmers and minimum $(₹ 1,80,924.52)$ for medium farmers.

Among the different items of cash expenditure, the plucking \& carriage charge/harvesting charging (₹) and value of packing material are highest as $25.91 \%$ and $24.54 \%$ respectively of the total cost. The other per hectare expenditure 
are the value of manure \& fertilizer $(4.56 \%)$, cost of plants $(8.81 \%)$, value of insecticides \& pesticides $(13.03 \%)$, freight charges (6.04\%), transportation charges (14.73\%).

Cost Structure and Returns:-

A. Estimates of different costs: Estimates of different costs such as cost A1, cost A2, cost B1, cost B2, cost C1, cost $\mathrm{C} 2$ and cost $\mathrm{C} 3$ as explained in earlier section are presented in Table 4 . The table 4 shows that the overall per hectare Cost-A1 came to ₹ 2,45,124.79. The highest per hectare Cost-A1 is ₹ 3,45,110.55 for marginal farms and lowest ₹ 1,80,924.52 for medium farms. The study also shows that Cost-B2 and Cost-C2 accounted for about 90.75 and 90.91 per cent of the total cost C3. On an average, Cost-C3 came to ₹ 4,30,863.77 per hectare which is highest on marginal farms $(5,57,751.55$ per hectare) and lowest on medium farms $(3,52,386.03$ per hectare).

B- Yield, price, gross income and net gains: Yield, farm harvest price and value of gross output from horticulture crops production on different farm size groups are presented in Table 5. It shows that the average yield is ₹ $8,86,258.29$ per hectare. It ranged from ₹ 9,86,313.35 on medium farms to ₹ 7,70,226.50 on small farms.

The results (Table 5) show that average farm harvest price is ₹ 2,33,757.30. It is highest for marginal farmers (₹ $3,45,100.55$ ) and lowest to medium farmers ( $₹ 1,80,924.79$ ). This is due to

large farm growers sell their produce at higher prices compared to medium farms, which was mainly due to time of sale and agencies to which the produce was sold.

The average gross returns per hectare amounted to ₹ 6,53,081.77. It varied from ₹ 8,05,388.83 on medium farms and ₹ 5,31,721.04 on marginal farms. The gross income is highest on medium farms followed by semi-medium, small and marginal farms.

Table 3:- Input use Pattern of Horticultural Crops (Apple,Pears,Plums \& Alomand) per hectare. Figure in parenthesis indicate percentages to Cost-C3.

Source: Field Survey.

\begin{tabular}{|l|l|c|c|c|c|c|}
\hline S.N. & Item & \multicolumn{5}{|c|}{ Category of Farm } \\
\cline { 3 - 7 } & & $\begin{array}{c}\text { Marginal } \\
\text { Farmers }\end{array}$ & $\begin{array}{c}\text { Small } \\
\text { Farmers }\end{array}$ & $\begin{array}{c}\text { Semi- } \\
\text { medium }\end{array}$ & Medium & All Farms \\
\hline 1 & Human Labour ( in mandays) & 319.84 & 161.38 & 63.98 & 55.22 & 164.99 \\
\hline 2 & Land in Hectare & 27.67 & 17.15 & 24.84 & 15.61 & 85.27 \\
\hline 3 & Value of manure \& fertilizer & 20193.15 & 11595.67 & 5041.51 & 4529.68 & 11182.46 \\
& $(₹)$ & $(5.85)$ & $(5.47)$ & $(2.56)$ & $(2.50)$ & $(4.56)$ \\
\hline 4 & Cost of Plants (₹) & 29637.34 & 24022.20 & 15501.50 & 14410.42 & 21602.33 \\
& & $(8.59)$ & $(11.33)$ & $(7.87)$ & $(7.96)$ & $(8.81)$ \\
\hline 5 & Value of Insecticides \& & 53600.22 & 32943.07 & 17514.69 & 15371.12 & 31934.38 \\
& pesticides (₹) & $(15.53)$ & $(15.53)$ & $(8.89)$ & $(8.50)$ & $(13.03)$ \\
\hline 6 & Plucking \& Carriage & 121540.18 & 62939.43 & 25271.36 & 22088.04 & 63502.09 \\
& Charge/Harvesting Charging & $(35.22)$ & $(29.68)$ & $(12.83)$ & $(12.21)$ & $(25.91)$ \\
& $(₹)$ & & & & & \\
\hline 7 & Value of packing Material $(₹)$ & 52165.34 & 44429.42 & 71266.66 & 73941.48 & 60160.48 \\
& & $(15.12)$ & $(20.95)$ & $(36.19)$ & $(40.87)$ & $(24.54)$ \\
\hline 8 & Freight Charges (₹) & 15443.95 & 10932.44 & 15541.77 & 16780.14 & 14809.67 \\
& & $(4.48)$ & $(5.16)$ & $(7.89)$ & $(9.27)$ & $(6.04)$ \\
\hline 9 & Transportation Charges $(₹)$ & 44853.59 & 19934.93 & 42204.36 & 28628.71 & 36098.87 \\
& & $(13.00)$ & $(9.40)$ & $(21.43)$ & $(15.82)$ & $(14.73)$ \\
\hline 10 & Marketing Charges (₹) & 7676.79 & 5265.06 & 4590.06 & 5174.94 & 5834.50 \\
& & $(2.22)$ & $(2.48)$ & $(2.33)$ & $(2.86)$ & $(2.38)$ \\
\hline 11 & Total Cost & 345110.55 & 212062.22 & 196931.90 & 180924.52 & 245124.79 \\
& & $(100.00)$ & $(100.00)$ & $(100.00)$ & $(100.00)$ & $(100.00)$ \\
\hline
\end{tabular}

Per hectare net Returns:-

Table 6 shows that per hectare net returns over operational cost (Cost-A1) was the highest (₹ 8,05,388.83) on medium farms and the lowest (₹ 5,31,721.04) on marginal farms with on an average of ₹ 6,41,133.50 on all farms. Net income from marginal, small, semi-medium and medium farms is ₹ $-26,030.51$, ₹ $1,96,835.71$, ₹ 3,45,316.07, ₹ $4,53,002.8$ per hectare, respectively. The net income over marginal farms is negative. It is apparent from the table 
that per hectare net returns on different farms over Cost C3 ranged from ₹ 6,33,927.32 on medium farms to ₹ $3,19,080.04$ on marginal farms with an overall of ₹ 4,55,394.52 per hectare. The net income rate shows increase with increasing size of farm.

Table 4:- Estimates of different costs.

\begin{tabular}{|c|c|c|c|c|c|c|c|}
\hline \multirow{2}{*}{$\begin{array}{l}\text { Category } \\
\text { of Farms }\end{array}$} & \multicolumn{7}{|c|}{ Different costs (per hectare ) } \\
\hline & Cost-A1 & Cost-A2 & Cost-B1 & Cost-B2 & Cost-C1 & Cost-C2 & Cost-C3 \\
\hline Marginal & $\begin{array}{c}345110.55 \\
(61.88)\end{array}$ & $\begin{array}{c}345110.55 \\
(61.88) \\
\end{array}$ & $\begin{array}{c}386523.82 \\
(69.30)\end{array}$ & $\begin{array}{c}503001.18 \\
(90.18)\end{array}$ & $\begin{array}{c}390569.50 \\
(70.23) \\
\end{array}$ & $\begin{array}{c}507046.86 \\
(90.91)\end{array}$ & $\begin{array}{c}557751.55 \\
(100.00)\end{array}$ \\
\hline Small & $\begin{array}{c}212062.22 \\
(58.69) \\
\end{array}$ & $\begin{array}{c}212062.22 \\
(58.69)\end{array}$ & $\begin{array}{c}237509.69 \\
(65.73) \\
\end{array}$ & $\begin{array}{c}325187.05 \\
(90.00) \\
\end{array}$ & $\begin{array}{c}240803.16 \\
(66.64) \\
\end{array}$ & $\begin{array}{c}328480.52 \\
(90.91) \\
\end{array}$ & $\begin{array}{r}361328.57 \\
(100.00) \\
\end{array}$ \\
\hline $\begin{array}{l}\text { Semi- } \\
\text { medium }\end{array}$ & $\begin{array}{c}196931.90 \\
(52.98)\end{array}$ & $\begin{array}{c}196931.90 \\
(52.98) \\
\end{array}$ & $\begin{array}{c}220563.73 \\
(59.33)\end{array}$ & $\begin{array}{c}337041.09 \\
(90.67)\end{array}$ & $\begin{array}{c}221465.22 \\
(59.58)\end{array}$ & $\begin{array}{c}337942.5 \\
(90.91)\end{array}$ & $\begin{array}{c}371736.84 \\
(100.00)\end{array}$ \\
\hline Medium & $\begin{array}{c}180924.52 \\
(51.34) \\
\end{array}$ & $\begin{array}{c}180924.52 \\
(51.34) \\
\end{array}$ & $\begin{array}{c}202635.46 \\
(57.50) \\
\end{array}$ & $\begin{array}{c}319112.82 \\
(90.56)\end{array}$ & $\begin{array}{c}203873.58 \\
(57.86) \\
\end{array}$ & $\begin{array}{c}320350.94 \\
(90.91) \\
\end{array}$ & $\begin{array}{c}352386.03 \\
(100.00) \\
\end{array}$ \\
\hline Overall & $\begin{array}{c}245124.79 \\
(56.89) \\
\end{array}$ & $\begin{array}{c}245124.79 \\
(56.89) \\
\end{array}$ & $\begin{array}{c}274539.76 \\
(63.72) \\
\end{array}$ & $\begin{array}{c}391017.12 \\
(90.75) \\
\end{array}$ & $\begin{array}{c}275216.98 \\
(63.88) \\
\end{array}$ & $\begin{array}{c}391694.34 \\
(90.91) \\
\end{array}$ & $\begin{array}{c}430863.77 \\
(100.00) \\
\end{array}$ \\
\hline
\end{tabular}

Figure in parenthesis indicate percentages to Cost-C3.

Source: Field Survey.

Table 5:- Yield Level, Farm Harvest Price and Gross Income per hectare.

\begin{tabular}{|c|c|c|c|}
\hline Category of Farms & $\begin{array}{c}\text { Yield } \\
\text { ₹ /Hectare }\end{array}$ & $\begin{array}{c}\text { Harvest Price } \\
\text { ₹ / Hectare }\end{array}$ & $\begin{array}{c}\text { Value of Gross Output } \\
\text { ₹ / Hectare }\end{array}$ \\
\hline Marginal Farmers & 876831.59 & 345110.55 & 531721.04 \\
\hline Small Farmers & 770226.50 & 212062.22 & 558164.28 \\
\hline Semi-medium & 913984.81 & 196931.90 & 717052.91 \\
\hline Medium & 986313.35 & 180924.52 & 805388.83 \\
\hline All Farms & 886258.29 & 245124.79 & 641133.50 \\
\hline
\end{tabular}

Table 6:- Net gain over different costs per hectare

\begin{tabular}{|c|c|c|c|c|c|c|c|}
\hline \multirow{2}{*}{$\begin{array}{l}\text { Category } \\
\text { of Farms }\end{array}$} & \multicolumn{7}{|c|}{ Net gain over different costs } \\
\hline & Cost-A1 & Cost-A2 & Cost-B1 & Cost-B2 & Cost-C1 & Cost-C2 & Cost-C3 \\
\hline $\begin{array}{l}\text { Marginal } \\
\text { Farmers }\end{array}$ & 531721.04 & 531721.04 & 490307.77 & 373830.41 & 486262.09 & 369784.73 & 319080.04 \\
\hline $\begin{array}{l}\text { Small } \\
\text { Farmers }\end{array}$ & 558164.28 & 558164.28 & 532716.81 & 445039.45 & 529423.34 & 441745.98 & 408897.93 \\
\hline $\begin{array}{l}\text { Semi- } \\
\text { medium }\end{array}$ & 717052.91 & 717052.91 & 693421.08 & 576943.72 & 692519.59 & 576042.31 & 542247.97 \\
\hline Medium & 805388.83 & 805388.83 & 783677.89 & 667200.53 & 782439.77 & 665962.41 & 633927.32 \\
\hline All Farms & 641133.50 & 641133.50 & 611718.53 & 495241.17 & 611041.31 & 494563.95 & 455394.52 \\
\hline
\end{tabular}

Per hectare FBI, FLI and FII and net profit: The overall per hectare farm business income, family labour income and farm investment income as in shown in Table 7 are ₹ 3,96,008.71, ₹ 3,96,008.71 and ₹ 3,66,593.74 respectively. The data further revealed that the net profit per hectare (over Cost-C3) is and ₹ 2,10,269.7 for all farm groups.

Table 7:- Farm business income, family labour income, farm investment income and net income over cost C3 (/hectare)

\begin{tabular}{|l|l|l|l|l|l|}
\hline Category of Farms & $\begin{array}{l}\text { Marginal } \\
\text { Farmers }\end{array}$ & $\begin{array}{l}\text { Small } \\
\text { Farmers }\end{array}$ & $\begin{array}{l}\text { Semi- } \\
\text { medium }\end{array}$ & Medium & All Farms \\
\hline Farm business income & 186610.49 & 346102.06 & 520121.01 & 624464.31 & 396008.71 \\
\hline Family labour income & 186610.49 & 346102.06 & 520121.01 & 624464.31 & 396008.71 \\
\hline Farm investment income & 145197.22 & 320654.59 & 496489.18 & 602753.37 & 366593.74 \\
\hline Net Income & -26030.51 & 196835.71 & 345316.07 & 453002.8 & 210269.7 \\
\hline
\end{tabular}

Estimation of Resource use Efficiency:- 
Resource use efficiency means how efficiently the farmer can use his resources in production process. It is very important because our resources are very limited. For calculating resource use efficiency we considered ten factors viz., human labour (in mandays), land in hectare, value of manure \& fertilizer, cost of plants (₹), value of insecticides \& pesticides (₹), plucking \& carriage charge/harvesting charging (₹), value of packing material (₹), freight charges $(₹)$, transpotation charges $(₹)$ and marketing charges $(₹)$. The data collected from the respondents is used for regression analysis so as to determine the relationship between inputs and the output of crops. The results obtained are shown in the Table 8.

Table 8:- Resource use efficiency of horticulture crop:

\begin{tabular}{|l|c|c|c|}
\hline Variables & $\begin{array}{c}\text { Regression } \\
\text { Coefficient }\end{array}$ & $\begin{array}{c}\text { Std. } \\
\text { Error }\end{array}$ & $\begin{array}{c}\text { Calculated } \\
\text { 't' }\end{array}$ \\
\hline a & -6.3648 & 2.9604 & $-2.15^{*}$ \\
\hline Human Labour $\left(\mathrm{X}_{1}\right)$ & -3.0166 & 1.1611 & $-2.598^{*}$ \\
\hline Land in Hectare $\left(\mathrm{X}_{2}\right)$ & 0.036 & 0.023 & 1.5635 \\
\hline Value of manure \& fertilizer $\left(\mathrm{X}_{3}\right)$ & -0.0197 & 0.0395 & -0.498 \\
\hline Cost of Plants $\left(\mathrm{X}_{4}\right)$ & 0.0544 & 0.0272 & $1.9983^{*}$ \\
\hline Value of Insecticides \& pesticides $\left(\mathrm{X}_{5}\right)$ & 0.0846 & 0.0471 & 1.7941 \\
\hline Plucking \& Carriage Charge/Harvesting Charging $\left(\mathrm{X}_{6}\right)$ & 3.0071 & 1.1621 & $2.5877^{*}$ \\
\hline Value of packing Material $\left(\mathrm{X}_{7}\right)$ & 0.1717 & 0.0345 & $4.9809^{* *}$ \\
\hline Freight Charges $\left(\mathrm{X}_{8}\right)$ & 0.2595 & 0.0439 & $5.9084^{* *}$ \\
\hline Transportation Charges $\left(\mathrm{X}_{9}\right)$ & 0.1882 & 0.0344 & $5.4756^{* *}$ \\
\hline Marketing Charges $\left(\mathrm{X}_{10}\right)$ & 0.3256 & 0.0393 & $8.2743^{* *}$ \\
\hline
\end{tabular}

* Significant at $5 \%$ level of significance. ${ }^{* *}$ Highly significant at $1 \%$ level of significance

The results showed that the inputs human labour (in mandays) and value of manure \& fertilizer are negatively related to output, while all other inputs are positively related to the output. The $\mathrm{R}^{2}$ of 0.9810 implied that $98.10 \%$ of total variation in the output is explained by the inputs specified in the Cobb-Douglas production function. The positive regression co-efficient indicating that a unit increases in any of the variable holding others constant will lead to a unit increase in the gross output.

The regression equation is

$\mathrm{Y}=-6.3648-3.0166 \mathrm{X}_{1}+0.036 \mathrm{X}_{2}-0.0197 \mathrm{X}_{3}+0.0544 \mathrm{X}_{4}+0.0846 \mathrm{X}_{5}+3.0071 \mathrm{X}_{6}+0.1717 \mathrm{X} 7+0.2595 \mathrm{X}_{8}+0.1882$ $\mathrm{X}_{9}+0.3256 \mathrm{X}_{10}$

In the above equation, Intercept $=\ln \mathrm{a}=-6.3648$

Therefore, $\mathrm{A}=\mathrm{e}^{-6.3648}=0.001721$

Thus, the estimated equation in its multiplicative form is:

$\mathrm{Y}=(0.001721) \mathrm{X}_{1}^{-3.0166} \mathrm{X}_{2}{ }^{0.036} \mathrm{X}_{3}^{-0.0197} \mathrm{X}_{4}{ }^{0.0544} \mathrm{X}_{5}{ }^{0.0846} \mathrm{X}_{6}^{3.0071} \mathrm{X}_{7}^{0.1717} \mathrm{X}_{8}{ }^{0.2595} \mathrm{X}_{9}^{0.1882} \mathrm{X}_{10}{ }^{0.3256}$

In the regression the values of $\mathrm{R}$ is 0.9905 and the standard error of estimate is 0.0640

To test whether there is any significant difference between the average cost/ha of cultivation among the two farm sizes a ' $t$ ' test is carried out. For this purpose Shapiro-Wilk test of normality is done for the cost of cultivation. The regression co-efficient of value of packing material, freight charges, transportation charges and marketing charges are significant at 1 percent level which indicated that holding other factors constant one percent increase in these variables would increase the gross return by $0.1717,0.2595,0.1882$ and 0.3256 respectively. While the cost of plants i.e 0.0544 which is positive and statistically significant, indicated that increase in the input will significantly effect on yield. If expenses made on cost of plants will gives profitable returns.

The elasticity of production (Ep) of all the variables summed up to 0.9810 meaning decreasing return to scale, implying that, if these resources are increase by $1 \%$, the output would increases by less than $1 \%$ except in case of human labour and value of manure \& fertilizer variables. The F - values of the equation derived for farmer is 313.0509, which is highly significant at 1 percent level implying that all the explanatory variables were important for explaining the variations in gross returns. 


\section{Conclusions:-}

From the horticulture cultivation in Kotgarh valley of Shimla district (Himachal Pradesh) following conclusions are drawn, The average total cost of cultivation is ₹ 2,45,124.79 per hectare for all marginal, small, semi-medium and medium farmers; which is highest (₹ $3,45,110.55)$ for marginal farmers and minimum $(₹ 1,80,924.52)$ for medium farmers The average yield is ₹ 8,86,258.29 per hectare. It ranged from ₹ 9,86,313.35 on medium farms to ₹ $7,70,226.50$ on small farms. The overall per hectare farm business income, family labour income and farm investment income is ₹ 3,96,008.71, ₹ 3,96,008.71 and ₹ 3,66,593.74 respectively. The data further revealed that the net profit per hectare (over Cost-C3) is and ₹ 2,10,269.7 for all farm groups. Functional analysis of horticulture crops revealed that, cultivated land, cost of plants, value of insecticides \& pesticides, plucking \& carriage charge/harvesting charges, value of packing material, freight charges, transportation charges and marketing charges i.e. $0.036,0.0544,0.0846,3.0071,0.1717,0.2595,0.1882$ and 0.3256 respectively. This is positive and statistically significant, which indicated that if expenses made on these resources, then it will be gives profitable returns. The regression co-efficient of value of packing material, freight charges, transportation charges and marketing charges are significant at 1 percent level which indicated that holding other factors constant one percent increase in these variables would increase the gross return by $0.1717,0.2595,0.1882$ and 0.3256 respectively. While the cost of plants i.e 0.0544 which is positive and statistically significant, indicated that increase in the input will significantly effect on yield. If expenses made on cost of plants will gives profitable returns. The elasticity of production (Ep) of all the variables summed up to 0.9810 meaning decreasing return to scale, implying that, if these resources are increase by $1 \%$, the output would increases by less than $1 \%$ except in case of human labour and value of manure $\&$ fertilizer variables. The $\mathrm{F}$ - values of the equation derived for farmer is 313.0509 , which is highly significant at 1 percent level implying that all the explanatory variables were important for explaining the variations in gross returns.

\section{References:-}

1. Cobb CW and Douglas PH (1928). "A Theory of Production" (PDF). American Economic Review. 18 (Supplement): 139-165.

2. Kahlon AS and Singh K (1984). Managing agricultural finance. Food and Agriculture organization of United States.

3. Patil AH and Kobarkar VK (2013). Resource use efficiency in wheat production of Amavati Division. Indian Journal of Applied Research, 3:10-11.

4. Raju DVN and Rao KL (1990). Studies on the performance of different sugarcane varieties when crushed late in the season. Bharatiya Sugar, 16(1), 169-176.

5. Sharma DK, Prashad S and Kumar A (2015). Scenario of co-operative movement in Himachal Pradesh. International Journal of Advanced Research, 3(1), 307-323.

6. Sureshkumar AP, Asodiya PS, Parmar VK and Patel KS. (2014). Input use, costs structure, return and resource use efficincy analysis of wheat crop in south Gujarat, India. International Journal of Agricultural Extension, 2(1), 05-12.

7. http://www.hpagrisnet.gov.in/hpagris/Horticulture (last assessed on 15 June 2017) 